\title{
The Learning of Adolescent Students about the Disabled Person Using Board Game
}

\author{
Fátima Karine Apolonio Vasconcelos*, Lorita Marlena Freitag Pagliuca, \\ Aline Tomaz de Carvalho, Mariana Gonçalves de Oliveira, Paulo César de Almeida \\ Department of Nursing, Universidade Federal do Ceará, Fortaleza, Brazil \\ Email: ${ }^{*}$ fkarinev@hotmail.com
}

Received 16 February 2015; accepted 2 March 2015; published 6 March 2015

Copyright @ 2015 by authors and Scientific Research Publishing Inc.

This work is licensed under the Creative Commons Attribution International License (CC BY). http://creativecommons.org/licenses/by/4.0/

(c) () D Open Access

\section{Abstract}

This study aims at verifying the learning of adolescent students about the disabled person using educational technology in the board game mode and using a semi-experimental non-randomized study of pre and post with unintentional probability sample. Validated and standardized instruments were used. Data were processed by SPSS 20.0 and organized in tables. For comparison of proportions, the McNemar test was used. Females predominated (56\%), aged between 13 and 14 years old (63.3\%) from private schools (58.7\%). It was evidenced a significance for learning about visual and hearing impairment on issues of low complexity $(p<0.0001)$, visual impairment in the issue of medium complexity $(p<0.0001)$ and hearing loss in high complexity $(p<0.0001)$. It should be practiced using the board game to school awareness about the theme, because it provides reflection on the theme, contributes to learning and encourages inclusion.

\section{Keywords}

Nursing Care, Nursing, Education in Nursing, Educational Technology, People with Disabilities

\section{Introduction}

Schools, considered institutions of great significance where teenagers spend a part of their lives, provide identity formation. These institutions are perceived as training and information space, where reflections are motivated, concerns are remedied by promoting awareness in order to making students becoming human beings capable of conscious choices and taking responsible decisions [1].

Features adolescence as a phase transformation in which the subjects are intended for biological evolution to maturity, reconstituting identity references, located between childhood and the adult world. In general, it is time

\footnotetext{
${ }^{*}$ Corresponding author.
}

How to cite this paper: Vasconcelos, F.K.A., Pagliuca, L.M.F., de Carvalho, A.T., de Oliveira, M.G. and de Almeida, P.C. (2015) The Learning of Adolescent Students about the Disabled Person Using Board Game. Open Journal of Nursing, 5, $173-180$. http://dx.doi.org/10.4236/ojn.2015.53021 
where there is clarification of values, decision-making, for statement, freedom, independence, curiosity and change [2].

The literature recognizes the importance of thematic approach Person with Disability for school adolescents, with discussions about stigma, prejudice, attitudinal barriers, acceptance of differences, so that there is real respect and inclusion of this layer in society [3]. Worldwide, more than a billion people have any disabilities, among which about 200 million present with considerable functional difficulties [4].

Attitudinal changes of the population in relation to people with disabilities, combined with the curiosity and willingness to learn of youth are recommended, therefore it is considered appropriate to approach the public school teenager of the theme, with the use of educational technology, so they can meet and learn to behave in front of a situation involving the disabled in their daily lives.

Educational technology in gaming mode has advantages such as competition and attention among players; the development of potential cognitive, affective and psychomotor domain, in addition to involvement, social interaction, alliances, mutual respect, improves performance in several aspects [5]. Board games allow desired content playful way, and encourage collaborative work in team. Also it gives the participants the opportunity to play several times and stay tuned to the game, for playing actively listening to questions and deliver answers, which stimulates learning pleasurable way [6].

The board game was developed in order to inform schoolchildren about the person with disabilities; created with dimensions 118, $8 \mathrm{~cm}$ high by $84 \mathrm{~cm}$ wide, with 22 stopping places on its route. The game has a total of 72 cards, being 29 guiding, 28 questions, 15 trivia, and four numbered pins. To be played in teams, it requires four participants. The first individual or team to reach the end wins the game.

The study aimed at verifying student teens learning about disabled person, using educational technology in board game mode.

\section{Method}

This is a quasi-experimental study, non-randomized, of type before and after [7]; held in public and private schools of the city of Fortaleza, Ceara, with ninth-grade students from elementary school. Non-probability sampling was intentional.

Text was supported in the literature addressing causes and prevention of disabilities, ways to communicate and conduct interactions with these people. This text has built up a question bank with 92 issues, sorted by complexity levels: low, medium and high. Three issues were drawn from each level. The knowledge assessment instruments contemplated nine issues, applied as pre and post educational activity. Affiliation pre-and post-test questions used to measure learning. Students attended schools in scheduled time, being informed about the strategy and objectives of the game.

Survey data were processed in the program SPSS 20.0 and organized in tables. For comparison of proportions before and after the educational activity, it used the McNemar test. The level of significance was of $5 \%$ ( $<<$ 0.05).

The development of the study attended national and international norms of ethics in research involving humans.

\section{Results}

Participated in the data collection 109 students, female gender predominated (56\%), aged between 13 and 14 years old (63.3\%) and from private school (58.7\%). Table 1 shows the variation in errors and successes during pre and posttest considering level of complexity of the subject and type of disability.

Low-complexity level, there was significance in the three issues addressed $(\mathrm{p}<0.0001)$ with increase of hits about item about visual impairment, hearing loss, and decreased on the issue about disability. Medium complexity level, the question of visual impairment obtained increase of hits ( $\mathrm{p}<0.0001)$, and high complexity level, the question of hard-of-hearing showed increase of hits $(\mathrm{p}<0.0001)$.

Regarding the gender difference, Table 2 shows the variation in errors and successes for the low-complexity level, females showed significance on the three issues ( $\mathrm{p}<0.0001)$, with an increase of hits on items about visual impairment, hearing loss, and a decrease of hits when it dealt with the physical disability. Males obtained significance ( $\mathrm{p}<0.0001$ ), with an increase of hits to two issues: visual and physical disabilities. The average complexity, there was significance in a matter, both in the female gender, with increase of hits to visual impairment, 
Table 1. Distribution of the number of school children according to errors and pre and post-test arrangements by level of complexity and type of disability. Fortaleza, CE, 2013.

\begin{tabular}{|c|c|c|c|c|c|c|c|c|c|}
\hline \multirow{3}{*}{$\begin{array}{l}\text { Level of Complexity/ } \\
\text { Disability }\end{array}$} & \multicolumn{4}{|c|}{ Pre-Test } & \multicolumn{4}{|c|}{ Post-Test } & \multirow{3}{*}{$\mathbf{p}$} \\
\hline & \multicolumn{2}{|c|}{ Error } & \multicolumn{2}{|c|}{ Right } & \multicolumn{2}{|c|}{ Error } & \multicolumn{2}{|c|}{ Right } & \\
\hline & $\mathbf{N}$ & $\%$ & $\mathbf{N}$ & $\%$ & $\mathbf{N}$ & $\%$ & $\mathbf{N}$ & $\%$ & \\
\hline \multicolumn{10}{|l|}{ Low } \\
\hline Visual & 102 & 93.6 & 7 & 6,4 & 62 & 56.9 & 47 & 43.1 & $<0.0001$ \\
\hline Hearing & 57 & 52.3 & 52 & 47.7 & 24 & 22.0 & 85 & 78.0 & $<0.0001$ \\
\hline Physical & 2 & 1.8 & 107 & 98.2 & 51 & 46.8 & 58 & 53.2 & $<0.0001$ \\
\hline \multicolumn{10}{|l|}{ Average } \\
\hline Visual & 51 & 46.8 & 58 & 53.2 & 11 & 10.1 & 98 & 89.9 & $<0.0001$ \\
\hline Hearing & 24 & 22.0 & 85 & 78.0 & 47 & 43.1 & 62 & 56.9 & 0.002 \\
\hline Physical & 102 & 93.6 & 7 & 6.4 & 101 & 92.7 & 8 & 7.3 & 1.000 \\
\hline \multicolumn{10}{|l|}{ High } \\
\hline Visual & 33 & 30.3 & 76 & 69.7 & 48 & 44.0 & 61 & 56.0 & 0.068 \\
\hline Hearing & 69 & 63.3 & 40 & 36.7 & 29 & 26.6 & 80 & 73.4 & $<0.0001$ \\
\hline Physical & 30 & 27.5 & 79 & 72.5 & 35 & 32.1 & 74 & 67.9 & 0.542 \\
\hline
\end{tabular}

Table 2. Distribution of the number of schoolchildren according to errors and pre and post-test arrangements by level of complexity, type of disability and gender. Fortaleza, CE, 2013.

\begin{tabular}{|c|c|c|c|c|c|c|c|c|c|}
\hline \multirow{3}{*}{$\begin{array}{l}\text { Level of Complexity/ } \\
\text { Gender }\end{array}$} & \multicolumn{4}{|c|}{ Pre-Test } & \multicolumn{4}{|c|}{ Post-Test } & \multirow{3}{*}{$\mathbf{p}$} \\
\hline & \multicolumn{2}{|c|}{ Error } & \multicolumn{2}{|c|}{ Right } & \multicolumn{2}{|c|}{ Error } & \multicolumn{2}{|c|}{ Right } & \\
\hline & $\mathbf{N}$ & $\%$ & $\mathbf{N}$ & $\%$ & $\mathbf{N}$ & $\%$ & $\mathbf{N}$ & $\%$ & \\
\hline \multicolumn{10}{|l|}{ Female } \\
\hline \multicolumn{10}{|l|}{ Low } \\
\hline Visual & 57 & 93.4 & 4 & 6.6 & 35 & 57.4 & 26 & 42.6 & $<0.0001$ \\
\hline Hearing & 35 & 57.4 & 26 & 42.6 & 12 & 19.7 & 49 & 80.3 & $<0.0001$ \\
\hline Physical & 2 & 3.3 & 59 & 96.7 & 39 & 49.2 & 31 & 50.8 & $<0.0001$ \\
\hline \multicolumn{10}{|l|}{ Average } \\
\hline Visual & 30 & 49.2 & 31 & 50.8 & 3 & 4.9 & 58 & 95.1 & $<0.0001$ \\
\hline Hearing & 15 & 24.6 & 46 & 75.4 & 20 & 32.8 & 41 & 67.2 & 0.441 \\
\hline Physical & 57 & 93.4 & 4 & 6.6 & 57 & 93.4 & 4 & 6.6 & 1.00 \\
\hline \multicolumn{10}{|l|}{ High } \\
\hline Visual & 16 & 26.2 & 45 & 73.8 & 28 & 45.9 & 33 & 54.1 & 0.038 \\
\hline Hearing & 36 & 59.0 & 25 & 41.0 & 15 & 24.6 & 46 & 75.4 & $<0.0001$ \\
\hline Physical & 17 & 27.9 & 44 & 72.1 & 18 & 29.5 & 43 & 70.5 & 1.000 \\
\hline \multicolumn{10}{|l|}{ Male } \\
\hline \multicolumn{10}{|l|}{ Low } \\
\hline Visual & 45 & 93.8 & 3 & 6.3 & 27 & 56.3 & 21 & 43.8 & $<0.0001$ \\
\hline Hearing & 22 & 45.8 & 26 & 54.2 & 12 & 25.0 & 36 & 75.0 & 0.031 \\
\hline Physical & 48 & 100.0 & - & - & 21 & 43.8 & 27 & 56.3 & $<0.0001$ \\
\hline \multicolumn{10}{|l|}{ Average } \\
\hline Visual & 21 & 43.8 & 27 & 56.3 & 8 & 16.7 & 40 & 83.3 & 0.015 \\
\hline Hearing & 9 & 18.8 & 39 & 81.3 & 27 & 56.3 & 21 & 43.8 & $<0.0001$ \\
\hline Physical & 45 & 93.8 & 3 & 6.3 & 44 & 91.7 & 4 & 8.3 & 1.000 \\
\hline \multicolumn{10}{|l|}{ High } \\
\hline Visual & 17 & 35.4 & 31 & 64.6 & 20 & 41.7 & 28 & 58.3 & 0.719 \\
\hline Hearing & 33 & 68.8 & 15 & 31.3 & 14 & 29.2 & 34 & 70.8 & $<0.0001$ \\
\hline Physical & 13 & 27.1 & 35 & 72.9 & 17 & 35.4 & 31 & 64.6 & 0.503 \\
\hline
\end{tabular}


as in the male, with a decrease of hits for deaf or hard of hearing. In high complexity, both genders also obtained significance $(p<0.0001)$ in question on deaf or hard of hearing. It was observed the same result as for physical disability for females $(\mathrm{p}=1.00)$, and in male, decrease of hits $(\mathrm{p}<0.503)$.

With respect to age (Table 3), the answers about visually impaired there was an increase in the number of hits on the issues of low and medium complexity in both age groups, $13-14$ years old and 15-17 $(\mathrm{p}<0.0001)$. On issues of high complexity, there was decrease in the range of $13-14$ years old $(p=0.043)$, remaining the same percentage in the range of $14-17(\mathrm{p}=0.839)$. Questions about hearing impaired, improved yield on the issues of low and high complexity $(\mathrm{p}<0.0001)$ getting worse on average complexity only in the range of 13 - 19 years $(\mathrm{p}=0.006)$.

Questions about disabled people had small number of hits at medium complexity in two age groups (5.8\% and $32.9 \%)$ and (7.5\% and $15 \%)$.

\section{Discussion}

The concept of disability remains in evolution, given that this is the result of interactions between an individual's disabilities and obstacles to their effective participation in society. As there are physical and attitudinal barriers that prevent their insertion and integration, more deficient will be the person [8].

Table 3. Distribution of the number of schoolchildren according to errors and pre and post-test arrangements by level of complexity, type of disability and age. Fortaleza, CE, 2013.

\begin{tabular}{|c|c|c|c|c|c|c|c|c|c|}
\hline \multirow{3}{*}{ Level of Complexity/Age } & \multicolumn{4}{|c|}{ Pre-Test } & \multicolumn{4}{|c|}{ Post-Test } & \multirow{3}{*}{$\mathbf{p}$} \\
\hline & \multicolumn{2}{|c|}{ Error } & \multicolumn{2}{|c|}{ Right } & \multicolumn{2}{|c|}{ Error } & \multicolumn{2}{|c|}{ Right } & \\
\hline & $\mathbf{N}$ & $\%$ & $\mathbf{N}$ & $\%$ & $\mathbf{N}$ & $\%$ & $\mathbf{N}$ & $\%$ & \\
\hline \multicolumn{10}{|l|}{13 - 14 Years Old } \\
\hline \multicolumn{10}{|l|}{ Low } \\
\hline Visual & 65 & 94.2 & 4 & 5.8 & 37 & 53.6 & 32 & 46.4 & $<0.0001$ \\
\hline Hearing & 28 & 40.6 & 41 & 59.4 & 14 & 20.3 & 55 & 79.9 & $<0.014$ \\
\hline Physical & 1 & 1.4 & 68 & 98.6 & 33 & 47.8 & 36 & 52.5 & $<0.0001$ \\
\hline \multicolumn{10}{|l|}{ Average } \\
\hline Visual & 31 & 44.9 & 38 & 55.1 & 4 & 5.8 & 65 & 94.2 & $<0.0001$ \\
\hline Hearing & 14 & 20.3 & 55 & 79.7 & 30 & 43.5 & 39 & 56.5 & 0.006 \\
\hline Physical & 65 & 94.2 & 4 & 5.8 & 67 & 97.1 & 2 & 2.9 & 0.687 \\
\hline \multicolumn{10}{|l|}{ High } \\
\hline Visual & 16 & 23.2 & 53 & 76.8 & 29 & 42.0 & 40 & 58.0 & 0.043 \\
\hline Hearing & 38 & 55.1 & 31 & 44.9 & 15 & 21.7 & 54 & 78.3 & $<0.0001$ \\
\hline Physical & 15 & 21.7 & 54 & 78.3 & 22 & 31.9 & 47 & 68.1 & 0.248 \\
\hline \multicolumn{10}{|l|}{15 - 17 Years Old } \\
\hline \multicolumn{10}{|l|}{ Low } \\
\hline Visual & 37 & 92.5 & 3 & 7.5 & 25 & 62.5 & 15 & 37.5 & 0.004 \\
\hline Hearing & 29 & 72.5 & 11 & 27.5 & 10 & 25.0 & 30 & 75.0 & $<0.0001$ \\
\hline Physical & 1 & 2.5 & 39 & 97.5 & 18 & 45.0 & 22 & 55.0 & $<0.0001$ \\
\hline \multicolumn{10}{|l|}{ Average } \\
\hline Visual & 20 & 50.0 & 20 & 50.0 & 7 & 17.5 & 33 & 82.5 & 0.011 \\
\hline Hearing & 10 & 25.0 & 30 & 75.0 & 17 & 42.5 & 23 & 57.5 & 0.167 \\
\hline Physical & 37 & 92.5 & 3 & 7.5 & 34 & 85.0 & 6 & 15.0 & 0.508 \\
\hline \multicolumn{10}{|l|}{ High } \\
\hline Visual & 17 & 45.2 & 23 & 57.5 & 19 & 47.5 & 21 & 52.5 & 0.839 \\
\hline Hearing & 31 & 77.5 & 9 & 22.5 & 14 & 35.0 & 26 & 65.0 & $<0.0001$ \\
\hline Physical & 15 & 37.5 & 25 & 62.5 & 13 & 32.5 & 27 & 67.5 & 0.804 \\
\hline
\end{tabular}


The population must be prepared to establishing effective relationships with persons with disabilities, to this must assimilate skills and attitudinal barriers, abandon. Health professionals report unpreparedness in relation to this audience, a fact noted early graduation, where nursing students showed that they rely on interpreters to communicate, meet without informing the procedures to be performed in consultation with nursing, and unaware of peculiarities of the clientele. Thus, training is essential to transform reality, being the result of awareness [9].

As a matter of human rights, it should minimize behavioral barriers faced by people with disabilities. Raising awareness by using educational strategies still in school age, and challenge negative attitudes, are initial steps for the accessibility of persons with disabilities [10].

Results show that educational game board mode favored students' learning about the persons with disabilities. Although the games are not a substitute for other teaching methods, this is motivating, fun and interactive strategy that aggregates content learning, constant development of ethical and healthy behavioral aspects [11]. This way, it understands how technological advances influence education. Thus confirms the need to associating it with new ways able to keeping students alert, interested in dynamic activities [12].

Content on visual, auditory and physical deficiencies had increase of hits performed by heterogeneously in each level of complexity. There was improvement in the learning of content on visual impairment and hearing on low complexity. The first content, the pre-test responses were obtained from affirmative about concept of congenital blindness. Students have not been successful, showing responses with large amount of errors. Studies of community health agents found difficulty on learning deep concepts and abstract as a person blind, low vision, even after the completion of a course of 40 hours [13]. There is a shortage of studies on congenital blindness, which contributes to greater ignorance about the subject and unpreparedness to dealing with the blind [14].

In the post-test, students were asked what factors do not cause eye trauma, with the following response options: traffic accidents; aging; physical attacks; chemicals. The increase in the number of hits has important repercussions since ocular trauma is the leading cause of monocular blindness and, after cataract is the most common cause of visual impairment [15]. To impacting the avoidable causes, it becomes important to education and supervision, with accident prevention measures, stringent requirement for protective gear at work, continuous supervision of children by adults while playing, and guidelines to prevent household accidents with sharp objects, acids, among others [16].

About hearing impairment, at the pre-test, it was described as a situational problem on communication with the deaf, whose correct alternative would be sign language. About half of the students reached the issue, suggesting that they have heard or had contact with the same. Used to establishing relation with/between deaf individuals, sign language conveys ideas, wishes and happenings [17].

Knowing the method of communicating with the Deaf provides approximation of your universe and promotes interaction between people with and without deafness. Social interactions are associated with psychological well being and related factors can be considered protective factors against pressures of life and the challenges of development, such as those faced by deaf children [18].

In the post-test treated with care on the hearing related to the use of electronic devices. Effects of noise and loud music are present in society, and have been a concern in recent years, especially among adolescents and adults, who hear frequently stereos [19]. Students reflected on the importance of listening to sound at low volume and avoid early problems in hearing. Most of the time the running game showed students using electronic devices and had interest and curiosity about the risk of deafness. Approximating activity to reality allows meeting and promoting health through education and training to acquire healthy habits [20].

It was observed that physical disability in low complexity showed a significant reduction in the number of hits. In the pre-test, the assertive brought situation where the lack of sensation in the legs should be named properly as disabilities. Almost all students answered correctly. On the other hand, the question about social integration theme addressed post-test, which should be set based on the example of the optimized access student with physical disabilities to mainstream school. This assertive presented reduction of almost half the hits on the question of the pre-test.

About issues of medium complexity the improvement of learning to dealing with visual impairment. The pre-and post-test questions cited the subject orientation and mobility of the blind person. The pre-test was about the importance of fitness of the guide dog as immunization and approximately half of the students missed the point. The guide dog is a guidance and resource mobility, must be used by adults only; it requires prior knowledge and conditions to treat it with care and maintenance, health and hygiene [21].

In comparison, the issue of orientation and mobility of approached post-test blinded by another person and 
showed significant increase in the number of hits. This issue strengthens the thought that the teaching about disabilities, added the training and experience is important both in schools and community experiences, clinics, because it contributes to the formation of the individual. May not exercise immediate changes; however, serves to making them aware and informing them about the deficiencies [22].

In the pre-test, the task about hearing in old age presents a significant number of hits. The increased amounts of elderly in the population, and of course, need for full and equal attention efforts. Continuing education of health teams, awareness of the population in order to ensuring the right of the elderly are some of the factors that can integrate and make the society participate effectively of this transformation [23].

However, there is a decrease of hits when it comes to the knowledge of the deaf and dumb. This term is loaded with prejudices, stereotyped and unpleasant for people with hearing loss, given that the deaf are not necessarily silent. In some cases, deaf people can make use of the appliance phonatory, unknown situation by students, which made them commit errors when answering the question [24]. High complexity level, hearing was the only theme that showed improvement in learning. The question of the pre-test treated about diseases that could cause deafness in a child of four months. Most students did not respond correctly. Thus, it emphasizes the importance of health education for the public in order to prevent disease and improve the quality of life, therefore, needing further explore concepts related to disease and disability.

In post-test, which dealt with the relationship between traffic accident and sequels in the hearing, there was significant increase in the number of hits. Polls show that three frequent causes of accidents that cause fracture of the temporal bone, causing hearing loss, are accidents with vehicles and motorcycles, falls and external violence [25]. Traffic accidents are important for public health, as well as frequent strikes the young population group preventable through educational programs, preventive, informational and normative [26].

Despite the female gender excelling to the male, the improvement of learning performed similarly in both groups. In contrast, a study that aimed to evaluating the concentrated attention of young people from 15 to 18 years old identified that the male is more swift and thoughtful responses, not wavering between highs and lows of concentration as female literacy, making mistakes and inattention [27].

Regarding the age groups, the lowest age group showed lower learning content on PcD. generally speaking, young people between 10 and 15 years old prefer active educational activities and peer interaction during these activities. They are intellectually curious about the world and about themselves and respond positively to opportunities to connect their realities to the content offered at school [28]. On the other hand, the older group accumulates experiences that translate into greater knowledge on the subject.

\section{Conclusions}

Implementation of educational technology provided knowledge about the topic, peculiarities about the PcD, prevention of disabilities, and relationship with people with visual, auditory and physical disabilities. Learning was significant in low-complexity issues in visual and auditory disabilities content, medium complexity on visual impairment, and high complexity, on hearing disabilities.

Results, in addition to refer to reflection about the importance of using the Board game in teaching about the PcD, contribute to participants' knowledge, awareness, inclusion and encourage use of the different thematic strategy for school education.

It points as limitation of the study, the intentional sample and the application in a given region. It is recommended with expanded populations studies about age and region of origin.

\section{References}

[1] Rodrigues, M.G.S., Cosentino, S.F., Rossetto, M., Maia, K.M., Pautz, M. and Silva, V.C. (2010) Oficinas educativas em sexualidade do adolescente: A escola como cenário. Enfermería Global, 20. http://scielo.isciii.es/scielo.php?script=sci_arttext\&pid=S1695-61412010000300009\&lng=es\&nrm=iso

[2] Souza, M. and Bertol, C.E. (2010) Transgressões e adolescência: Individualismo, autonomia e representações identitárias. Psicologia: Ciência e Profissão, 30, 824-839.

http://www.scielo.br/scielo.php?script=sci_arttext\&pid=S1414-98932010000400012\&lng=en\&nrm=iso

[3] Faro, A.C.M. and Gusmai, L.F. (2013) Inclusive Education in Nursing: Analysis of Students’ Needs. Revista da Escola de Enfermagem da USP, 47, 229-234.

http://www.scielo.br/scielo.php?script=sci_arttext\&pid=S0080-62342013000100029\&lng=en\&nrm=iso 
http://dx.doi.org/10.1590/S0080-62342013000100029

[4] World Report on Disability. World Health Organization (2011). http://www.who.int/disabilities/world_report/2011/report.pdf

[5] Akl, E.A., Kairouz, V.F. Sackett, K.M. Erdley, W.S., Mustafa, R.A., Fiander, M., Gabriel, C. and Schünemann, H.J. (2013) Educational Games for Health Professionals. Cochrane Database of Systematic Reviews, 3, 1-47.

[6] Gasparotto, A., Santo, M.V.P.E. and Silva, E.B. (2013) Jogo didático vira-vira: A metrópole vira colônia, a colônia vira metrópole. Revista Latino Americana de História, 2, 648-661. http://projeto.unisinos.br/rla/index.php/rla/article/view/222/176

[7] Polit, D.F. and Beck, C.T. (2011) Delineamento de Pesquisa em Enfermagem. In: Polit, D.F. and Beck, C.T., Eds., Fundamentos de pesquisa em enfermagem: Avaliação de evidências para prática de enfermagem, Artmed, Porto Alegre, 247-368.

[8] Garbe, D.S. (2012) Acessibilidade às pessoas com deficiência física e a convenção internacional de NovaIorque. Revista Unifebe (Online), 10, 95-104.

[9] Rebouças, C.B.A., Cezario, K.G., Oliveira, P.M.P. and Pagliuca, L.M.F. (2011) People with Physical and Sensory Deficits: Perceptions of Undergraduate Nursing Students. Acta Paulista de Enfermagem, 24, 80-86. http://dx.doi.org/10.1590/S0103-21002011000100012

[10] World Report on Disability. World Health Organization (2011). http://whqlibdoc.who.int/publications/2011/9789240685215 eng.pdf?ua=1

[11] Gibson, V. and Douglas, M. (2013) Criticality: The Experience of Developing an Interactive Educational Tool Based on Board Games. Nurse Education Today, 33, 1612-1616. http://dx.doi.org/10.1016/j.nedt.2013.01.022

[12] Santos, A.B. and Guimarães, C.R.P. (2010) A utilização de jogos como recurso didático no ensino de zoologia. Revista Electrónica de Investigación em Educación em Ciencias, 5, 52-57. http://www.scielo.org.ar/scielo.php?script=sci_arttext\&pid=S1850-66662010000200006\&lng=es\&nrm=iso

[13] Maia, E.R., Pagliuca, L.M.F. and Almeida, P.C. (2014) Learning of Community Health Agent to Identify and Register Disabled People. Acta Paulista de Enfermagem, 27, 326-332. http://dx.doi.org/10.1590/1982-0194201400055 http://www.scielo.br/scielo.php?script=sci arttext\&pid=S0103-21002014000400007\&lng=en\&nrm=iso

[14] Moura, W.F. and Oliveira, J.R.M. (2011) Estudo Descritivo comparativo de parâmetros de interação entre mãe e criança cega. Distúrbios da Comunicação, 23, 7-14.

[15] United State Eye Injury Registre (2014) Epidemiology. http://www.useironline.org/epidemiology

[16] Cabral, L.A., de Magalhães Nardelli Silva, T. and de Souza Britto, A.E.G. (2014) Traumas oculares no serviço de urgência da Fundação Banco de Olhos de Goiás. Revista Brasileira de Oftalmologia, 72, 383-387. http://www.scielo.br/scielo.php?script=sci arttext\&pid=S0034-72802013000600006\&lng=en http://dx.doi.org/10.1590/S0034-72802013000600006

[17] Ruiz, M.H.C., Shima, B.S.M. and Silva, T.S.A. (2014) O ensino da língua Brasileira de sinais na educação infantil para crianças ouvintes e surdas: Considerações com base na psicologia histórico-cultural. Revista Brasileira de Educação Especial, 19, 503-517. http://www.scielo.br/scielo.php?script=sci arttext\&pid=S1413-65382013000400003\&lng=en\&tlng=pt

[18] Batten, G., Oakes, P.M. and Alexander, T. (2013) Factors Associated with Social Interactions between Eaf Children and Their Hearing Peers: A Systematic Literature Review. Journal of Deaf Studies and Deaf Education, 12, 1-18.

[19] Figueiredo, R.R., Azevedo, A.A., Oliveira, P.M., Amorim, S.P.V., Rios, A.G. and Baptista, V. (2011) Incidence of Tinnitus in mp3 Player Users. Brazilian Journal Otorhinolaryngology, 77, 293-298. http://www.scielo.br/scielo.php?script=sci arttext\&pid=S1808-86942011000300004\&lng=en\&nrm=iso

[20] Santana, C.J., Scopinho, P.A.B., Ferreira, R.S., Simões, T.C. and Santos, J.N. (2009) Conhecimento auditivo da população usuária do Sistema Único de Saúde. Revista da Sociedade Brasileira de Fonoaudiologia, 14, 75-82. http://www.scielo.br/scielo.php?script=sci arttext\&pid=S1516-80342009000100013\&lng=en\&nrm=iso http://dx.doi.org/10.1590/S1516-80342009000100013

[21] Basto, L.S.C. and Gaio, R.C. (2010) Técnicas de orientação e mobilidade para pessoas cegas: Reflexões na perspectiva da educação física. Movimento \& Percepção, 11, 120-124.

[22] Shakespeare, T. and Kleine, I. (2013) Educating Health Professionals about Disability: A Review of Interventions. Health and Social Care Education, 2, 20-37. http://dx.doi.org/10.11120/hsce.2013.00026

[23] Paiva, K.M., Cesar, C.L.G., Alves, M.C.G.P., Barros, M.B.A., Carandina, L. and Goldbaum, M. (2011) Envelhecimento e deficiência auditiva referida: Um estudo de base populacional. Caderno de Saúde Pública, 27, 1292-1300. http://dx.doi.org/10.1590/S0102-311X2011000700005 http://www.scielo.br/scielo.php?script=sci_arttext\&pid=S0102-311X2011000700005\&lng=en\&nrm=iso 
[24] Espote, R., Serralha, C.A. and Comin, F.S. (2013) Inclusão de surdos: Revisão integrativa da literatura científica. Psico-USF, 18, 77-88. http://dx.doi.org/10.1590/S1413-82712013000100009 http://www.scielo.br/scielo.php?script=sci_arttext\&pid=S1413-82712013000100009\&lng=en\&nrm=iso

[25] Secchi, M.M.D., Moraes, J.F.S. and Castro, F.B. (2012) Fracture of the Temporal Bone in Patients with Traumatic Brain Injury. Arquivos Internacionais de Otorrinolaringologia, 16, 62-66. http://www.scielo.br/scielo.php?script=sci_arttext\&pid=S1809-48722012000100009\&lng=en\&nrm=iso http://dx.doi.org/10.7162/S1809-48722012000100009

[26] Vieira, L.J.E.S., Souza, E.R., Xavier, E.P., Lira, S.V.G. and Ferreira, R.C. (2010) Relatos da Equipe de Saúde quanto às Práticas Educativas ao Vitimado no Trânsito durante a Hospitalização/Reabilitação num Hospital de Emergência. Saúde e Sociedade, 19, 213-223. http://dx.doi.org/10.1590/S0104-12902010000100018

[27] Barbosa, A.C.M., Justen, D.E., Coser, J., Longhi, J.M., Bohm, T.E.F. and Calvetti, P.Ü. (2013) Prática do processo psicológico básico atenção em jovens da comunidade. Revista de Iniciação Cinetífica, 2, 191-204.

[28] Caskey, M. and Junior, V.A.A. (2014) Developmental Characteristics of Young Adolecents. Association for Middle Level Education.

http://www.amle.org/BrowsebyTopic/WhatsNew/WNDet/TabId/270/ArtMID/888/ArticleID/455/Developmental-Chara cteristics-of-Young-Adolescents.aspx 